\title{
Recent patent applications in antibody fragments
}

\begin{tabular}{|c|c|}
\hline Patent number & Description \\
\hline US 20110021755 & $\begin{array}{l}\text { An antibody or immunoadhesin comprising an } \\
\text { Fc variant of parent fragment crystallizable (Fc) } \\
\text { polypeptide; useful in pharmaceutical composi- } \\
\text { tions for preventing and/or treating autoimmune } \\
\text { or inflammatory disease. }\end{array}$ \\
\hline JP 2011007782 & $\begin{array}{l}\text { A method of measuring soluble interleukin-2 } \\
\text { receptor (sIL-2R) in a sample, comprising react- } \\
\text { ing a first antibody or its fragment that binds } \\
\text { sIL-2R with a magnetic particle in an aqueous } \\
\text { medium; reacting a second antibody coupled with } \\
\text { sIL-2R or its fragment with the complex in an } \\
\text { aqueous medium; isolating a magnetic particle } \\
\text { in the reaction liquid; and measuring the second } \\
\text { antibody on the magnetic particle. }\end{array}$ \\
\hline
\end{tabular}

WO 2011005481 An antibody or its antigen-binding fragment comprising the Fc region and method of its production, and a method of detecting or treating cancer, autoimmune, inflammatory or infectious diseases or disorders, comprising administering the antibody or its antigen binding fragment.

WO 2011002494, A method of binding aggregated amyloidogenic US 20110002945 proteins such as amyloid fibril or oligomer, involving exposing aggregated amyloidogenic proteins to an antibody chain, comprising heavy chain, light chain, or a portion of heavy or light chain of immunoglobulin.

US 20110003399 An isolated antibody or its fragment capable of binding specifically to protein or TNF- $\gamma$ protein; useful in a pharmaceutical composition for preventing and/or treating, e.g., cancer, cachexia, septic shock and malaria.

US 20110003383 An isolated antibody or its fragment capable of specifically binding to isolated HT5GJ57 polypeptide; used in a pharmaceutical composition for diagnosing and treating disorders, e.g., hyperproliferative disorders.
Medlmmune

(Gaithersburg, MD, USA)

DiMasi N, Gao C

$6 / 23 / 2009$

$1 / 13 / 2011$

University

(Philadelphia),

Adekar S, Dessain S,

O'Nuallain B,

University of Tennessee

Research Foundation

(Knoxville, TN, USA)

Human Genome

Sciences

(Rockville, MD, USA)

Human Genome

Sciences

(Rockville, MD, USA)

$7 / 15 / 1998$

$1 / 6 / 2011$

Ebner R, Endress GA,

Florence KA

Komatsoulis GA,

Lafleur DW, Moore PA,

Mucenski M, Olsen HS,

Rosen CA, Ruben SM,

Shi Y, Soppet DR, Young PE

HyTest

Katrukha AG,

$6 / 29 / 2009$

$1 / 6 / 2011$

originated by enzyme-dependent cleavage of insulin-like growth factor binding protein-4, comprising specific amino acid sequence or an amino acid sequence having at least $80 \%$ homology to specific amino acid sequence; useful for diagnosing, e.g., cancer.

US 20100330661 A device comprising a solid support that is useful for the detection and quantification of Ehrlichia ewingii, Ehrlichia ewingii antibodies, antibody fragments and polypeptides.

US 20100330595 A method of diagnosing hereditary hemochromatosis or chronic renal insufficiency, involving obtaining a tissue or fluid sample from the subject, contacting the sample with an antibody or its fragment and quantifying hepcidin level in the sample.

US 20100322931, An anti-vascular endothelial growth factor WO 2010148223 (VEGF) antibody or an anti-VEGF binding fragment of antibody, comprising complementarity determining regions having amino acid sequences corresponding to fully defined amino acids given in the specification; useful for treating cancer, age-related macular degeneration and immune disorders.
(Turku, Finland)

Kharitonov AV,

Postnikov AB,

Solovyeva TI
$1 / 6 / 2011$

Zhang J

11/7/1994

$1 / 6 / 201$

Adekar S, Dessa

$1 / 6 / 2011$

Publication date

$1 / 27 / 2011$

$1 / 13 / 2011$

date

$5 / 22 / 2009$ 